\title{
Effect of 4-MeSer-GnRH on the release and synthesis of gonadotropins in the female rat in vivo*
}

\section{K. Kochman', Alina Gajewska', Helena Kochman', Y. Lerrant ${ }^{2}$ and R. Counis ${ }^{2}$}

\author{
'The Kielanowski Institute of Animal Physiology and Nutrition, \\ Polish Academy of Sciences \\ 05-110 Jablonna, Poland \\ ${ }^{2}$ Laboratoire d'Endocrinologie Cellulaire et Moleculaire de la Reproduction, CNRS \\ 4 Place Jussieu, 75252 Paris, France
}

(Received 25 August 1997; accepted 24 October 1997)

\begin{abstract}
The experiment was performed to confirm selective stimulation of $\mathrm{FSH}$ release by $\mathrm{GnRH}$ analog 4-MeSer-GnRH and to determine if analog can act on $\alpha, \mathrm{LH} \beta$ and prolactin gene expression. Our studies in vivo have shown that 4-MeSer-GnRH FSH releasing potency was less expressed than it was shown in our previous experiments and that this peptide did not affect LH release. GnRH analog inhibited both pituitary prolactin and $\mathrm{LH} \beta \mathrm{mRNAs}$ level but this effect was much more strongly expressed in case of prolactin mRNA. Such data point out a necessity of more detailed studies on the biological properties of 4-MeSer-GnRH.
\end{abstract}

KEY WORDS: 4-MeSer-GnRH, GnRH, LH, FSH, pituitary, gonadotropin release, gonadotropin biosynthesis, mRNA

\section{INTRODUCTION}

Gonadotropin releasing hormone $(\mathrm{GnRH})$ plays a pivotal role in the regulation of reproduction through the stimulation of gonadotropin biosynthesis and secretion. Regulation of anterior pituitary function is mediated by the

\footnotetext{
* Supported by the State Committee for Scientific Research, Grant No 5 P06D 05108
} 
release of this neuropeptide into the primary portal capillaries in the median eminence and its delivery to the target via the hypophyseal portal veins. In mammals, the majority of GnRH neurons are situated in the hypothalamus and - functionally coupled - form a pulse generator that governs the pulse pattern of GnRH secretion and, in turn, gonadotropin secretion (Knobil, 1980). Among varied excitatory substances affecting GnRH release are: neuropepide Y, galanin, (Xu et al., 1996) amino acid glutamate (Brann, 1995) and gaseous diffusible messenger nitric oxide (Bonavera et al., 1996). Also an inhibitory neurotransmitters and neuromodulators are varied and they include opioids (Bonavera et al., 1993), tachykinins (Afione et al., 1990), GABA (Leonhardt et al., 1995). Feedback regulation on the gonadotrope can operate altering GnRH receptor number coupling to intracellular signal transduction pathways and the binding of $\mathrm{GnRH}$ to its receptors leads to stimulation of phospholipase activities in the plasma membrane of gonadotrope cell (Braden and Conn, 1993). The result of this activation is the cascade of physiological events leading to the relase of gonadotropins LH and FSH and to stimulation of their biosynthesis (Kochman and Gajewska, 1996).

Luteinizing hormone ( $\mathrm{LH})$ and follicle-stimulating hormone (FSH) are pituitary glycoprotein hormones that regulate gonadal function including the production of sex-steroid hormones, maturation of ovarian follicles in the female and development of spermatocytes in the male. They consist of a common $\alpha$ subunit and an unique, structurally related $\beta$ subunit. Each of those subunits $(\alpha, \mathrm{LH} \beta$ and $\mathrm{FSH} \beta)$ result from post-translational maturation of precursors that are encoded by separate genes (Gharib et al., 1990; Counis and Jutisz, 1991). The expression of $\alpha$ and $\beta$ subunit genes is regulated by a number of hormones including GnRH (Andrews et al., 1988; Starzec et al., 1989), gonadal steroids (Corbani et al,, 1990) and - isolated from gonadal fluid structurally related dimeric peptides - such as inhibin and activin (Attardi et al., 1989; Carroll et al., 1989; Vale et al., 1990). At the pituitary level, activins stimulate FSH secretion and synthesis (Carroll et al., 1989) but inhibit GH (Billestrup et al., 1990; Bilezikjian et al., 1990), ACTH (Bilezikjian et al., 1991) and PRL (Kitaoka et al., 1988) secretion and synthesis. Inhibins were shown to suppress FSH secretion and synthesis (Carroll et al., 1989).

Relations between $\mathrm{GnRH}$ and activin action seem to be very interesting. Katayama and Conn (1994) showed that activin increases the sensitivity of the system that regulates gonadotropin release to increases in cytosolic $\mathrm{Ca}^{2+}$ concentration and PKC activation .

In our studies on petides selectively releasing LH and FSH from the anterior pituitary gland in female rats we found (Kochman and Gajewska, 1990) that 4-MeSer-GnRH expressed activin-like activity by very potent and selective stimulatory effect on the FSH release. This study was performed to confirm this 
property of modified GnRH and to investigate how such modified peptide can act on gonadotropins and prolactin gene expression.

\section{MATERIAL AND METHODS}

Rats

Adult female Wistar rat of laboratory strain regularly cycling were used in the experiment. Both ovariectomy and injections into jugular vein and 3rd cerebral ventricle were performed under Narkamon anesthesia. Animal experiments were performed according to NIH regulations.

\section{Estimation of gene expression}

RNA extraction and hybridization. Total RNA was prepared according to Counis et al. (1981) method. Pituitaries were solubilized by lysis in $4 \mathrm{M}$ guanidine hydrochloride, $1 \%$ sodium sarcosinate, $0.1 \mathrm{M} \beta$-mercaptoethanol, $50 \mathrm{mM}$ sodium acetate $\mathrm{pH} 5$ and then centrifuged in a small tube (total volume $650 \mu \mathrm{l}$ ) on a $6 \mathrm{M} \mathrm{CsCl}$ cushion for $18 \mathrm{~h}$ in a Beckman ultra-centrifuge $\left(113.000 \mathrm{x} \mathrm{g}, 22^{\circ} \mathrm{C}\right)$. The RNA pellet $(10 \mu \mathrm{g})$ was recovered in $0.1 \mathrm{M}$ sodium acetate $-0.5 \%$ sodium dodecyl sulfate (SDS) and ethanol precipitated for dot or Northern hybridization analysis. Samples were electrophoresed in $1.5 \%$ agarose after glyoxal denaturation (McMasters and Carmichael, 1977), RNA was transfered onto a nylon filter (Hybond $\mathrm{N}$, Amersham, UK) and immobilized by baking according to the manufacture's recomendations. HindIII-digested lambda DNA and/or HinfT-digested pBR 322 DNA, ${ }^{32} \mathrm{P}$-labelled by filing of the 5 '-protruding ends with $\left[{ }^{35} \mathrm{~S}\right] \mathrm{dATP}$ and Klenow enzyme, were co-electrophoresed in wells adjacent to mRNA samples and thus cotransfered onto the membrane, to serve as size markers.

Prehybridization and hybridization were achieved as previously described (Corbani et al., 1990) at $42^{\circ} \mathrm{C}$ in the presence of $50 \%$ formamide, $5 \times$ SSC ( $1 \mathrm{xSC}=150 \mathrm{mM} \mathrm{NaCl}, 15 \mathrm{mM}$ trisodium citrate), $0.1 \%$ bovine serum albumin (BSA), $0.1 \%$ Ficoll, $0.1 \%$ polyvinylpyrrolidone, $0.1 \%$ sodium sarcosinate, $50 \mathrm{mM}$ phosphate buffer, $\mathrm{pH} 7,125 \mu \mathrm{g} / \mathrm{ml}$ sonicated salmon sperm DNA (Sigma Chemicals, St. Lois, MO, USA).

The complementary DNA (cDNA) probes. The rats $\alpha, \operatorname{LH} \beta$ and $\operatorname{FSH} \beta$ cDNA probes were fragments of cDNAs previously obtained in our laboratory subcloned in pUC vectors. Inserts excised from plasmids were labelled by random oligonucleotide priming to specific activities of approximately 
$2 \times 10^{9} \mathrm{cpm} / \mathrm{mg}$ using $\left[{ }^{-32} \mathrm{P}\right] \mathrm{dCTP}(400 \mathrm{Ci} / \mathrm{mmol})$ and the multiprime labelling kit (Amersham). The specific hybrids were revealed by autoradiography (X-OMAT-AR films, Kodak) and quantified by densitometry using a Hoefer GS 300 scanning densitometer.

\section{LH and FSH assay}

The concentration of $\mathrm{LH}$ and FSH in plasma samples was measured by RIA using reagents supplied by NIDDK with all samples from one experiment being assayed in triplicate in the same assay. The reference preparation used was rLH-RP-2 and rFSH-RP-3 and the minimum detectable concentration was 200 $\mathrm{pg} / \mathrm{ml}$. The intra- and interassay coefficients of variation were $<10 \%$.

\section{Statistical analysis}

Data are expressed as mean \pm SD. Statistical analysis of the data was performed using the unpaired and paired Student's t-test, as applicable. A P value of less than 0.05 was considered to be statistically significant.

\section{RESULTS}

Experimental data show that 4-MeSer-GnRH analog injected into jugular vein did not result in increased level of mean plasma $\mathrm{LH}$ neither after time-dependent injections (Figure 1) nor after dose-dependent injection (Figure 3). Injection of native $\mathrm{GnRH}$ caused very rapid $\mathrm{LH}$ release $(36.0 \pm 4.5 \mathrm{ng} / \mathrm{ml})$ compared to control $(2.9 \pm 0.4 \mathrm{ng} / \mathrm{ml})$. When we measured the mean plasma FSH level an increasing effect of 4-MeSer-GnRH was observed both after timedependent injections (Figure 2; $\mathrm{P}<0.05$ ) and after dose dependent injections (Figure 4; $\mathbf{P}<0.05$ ) but this analog was less potent $(12.8 \pm 0.7 \mathrm{ng} / \mathrm{ml})$ in $\mathrm{FSH}$ releasing than $\mathrm{GnRH}$ alone $(18.13 .8 \mathrm{ng} / \mathrm{ml} ; \mathrm{P}<0.05)$. FSH releasing ability of 4-MeSer-GnRH was not dependent neither on the time after injections - as the mean plasma level of this gonadotropin in comparison to control was the same after 15,30, and $60 \mathrm{~min}$ after i.v. injections - nor on administered dose of analog. There were no significant differences between FSH serum level after increasing dose of 4-MeSer-GnRH however the highest FSH concentration was found after $1 \mu \mathrm{g}$ analog injection $(17.5 \pm 1.2 \mathrm{ng} / \mathrm{ml})$ as compared to control $(12.7 \pm 0.7 \mathrm{ng} / \mathrm{ml})$.

After $5 \mathrm{~h}$ following intraventricular 4-MeSer-GnRH infusions pituitaries were excised and $\alpha, \mathrm{LH} \beta$, and prolactin mRNAs were estimated by Northern blot. We found that analog did not influence on subunit $\alpha$ mRNA expression but strongly lowered prolactin mRNA and $\mathrm{LH} \beta$ expression in the rat pituitary (Table 1). 


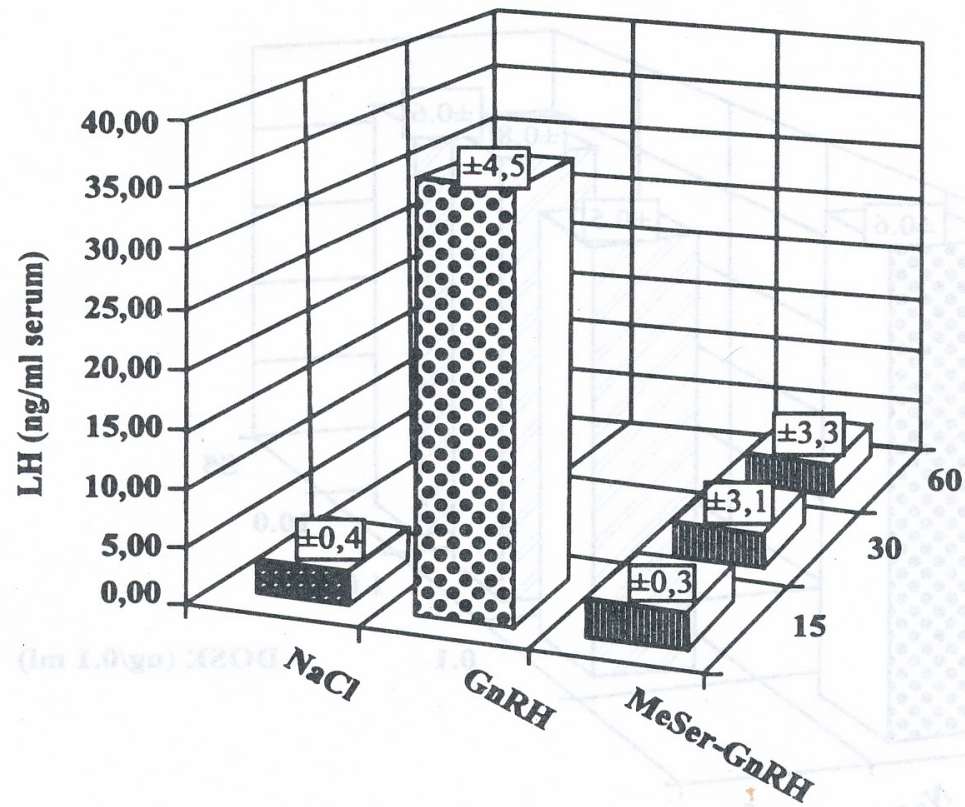

TIME (min) after injection

Figure 1. Serum LH release after 4-MeSer-GnRH i.v. injection to the female rat

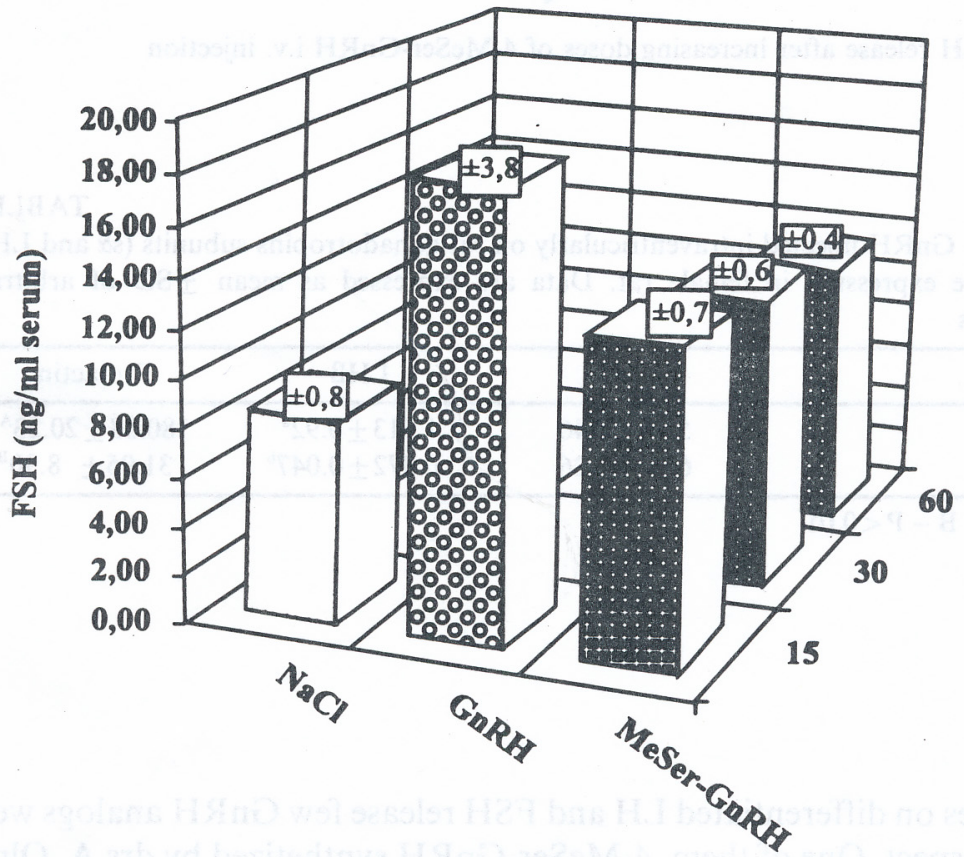

Figure 2. Serum FSH release after 4-MeSer-GnRH i.v. injections to the female rat 


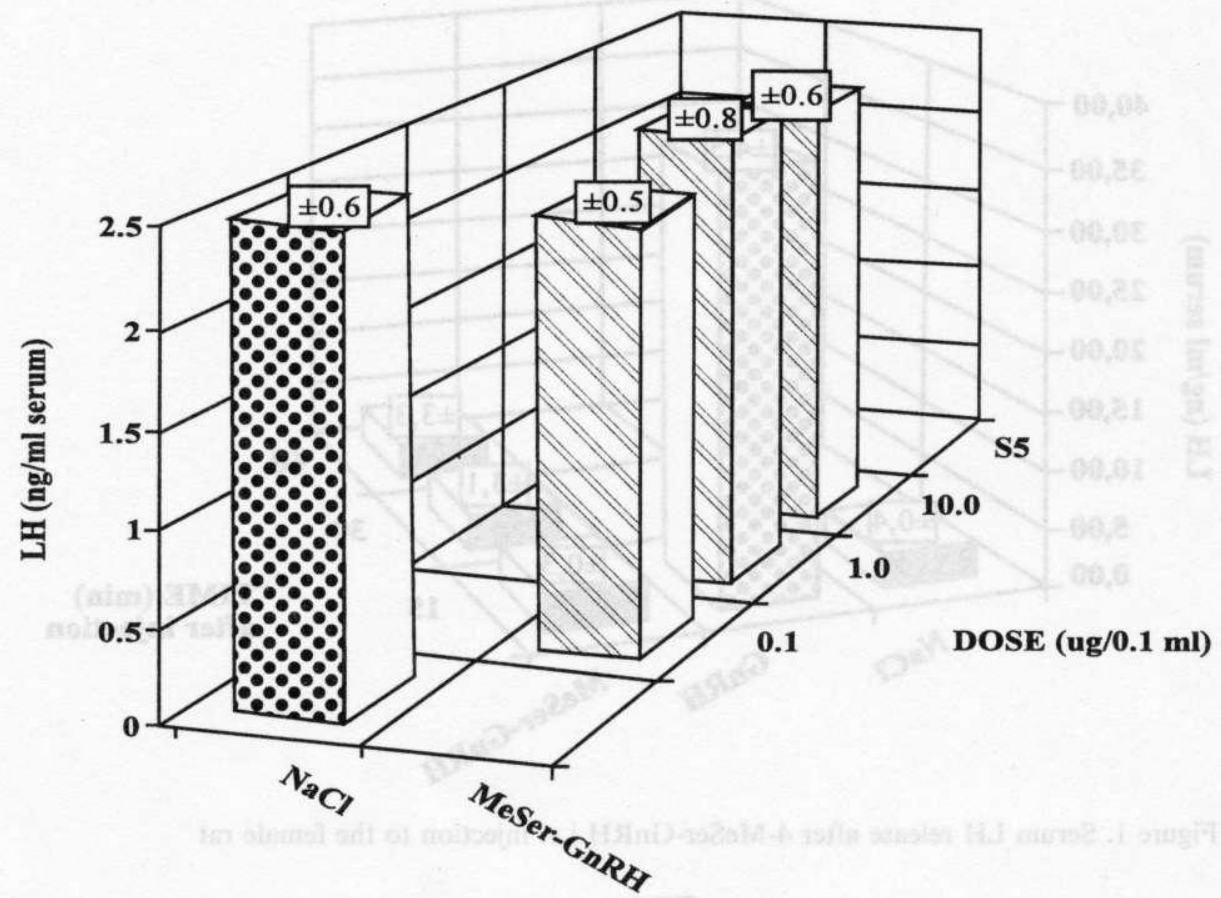

Figure 3. Serum LH release after increasing doses of 4-MeSer-GnRH i.v. injection

TABLE 1

Effect of 4-MeSer- GnRH injected intraventricularly on rat gonadotropins subunits ( $\alpha \alpha$ and LHB) and prolactin gene expression in female rat. Data are expressed as mean \pm SD of arbitrary densitometric units

\begin{tabular}{lccc}
\hline & $\alpha$ & LHB & Prolactin \\
\hline Control & $5.74 \pm 0.46$ & $1.013 \pm 0.92^{\mathrm{a}}$ & $180.08 \pm 20.23^{\mathrm{A}}$ \\
4-MeSer-GnRH & $6.00 \pm 0.26$ & $0.372 \pm 0.047^{\mathrm{b}}$ & $31.95 \pm 8.90^{\mathrm{B}}$ \\
\hline
\end{tabular}

$\mathrm{a}, \mathrm{b}-\mathrm{P}<0.05 ; \mathrm{A}, \mathrm{B}-\mathrm{P}<0.01$

\section{DISCUSSION}

In our studies on differentiated LH and FSH release few GnRH analogs were tested in this respect. One of them, 4-MeSer-GnRH synthetized by drs A. Olma and M. Leplawy (Technical University, Łódź) was very potent in evoking in vivo 


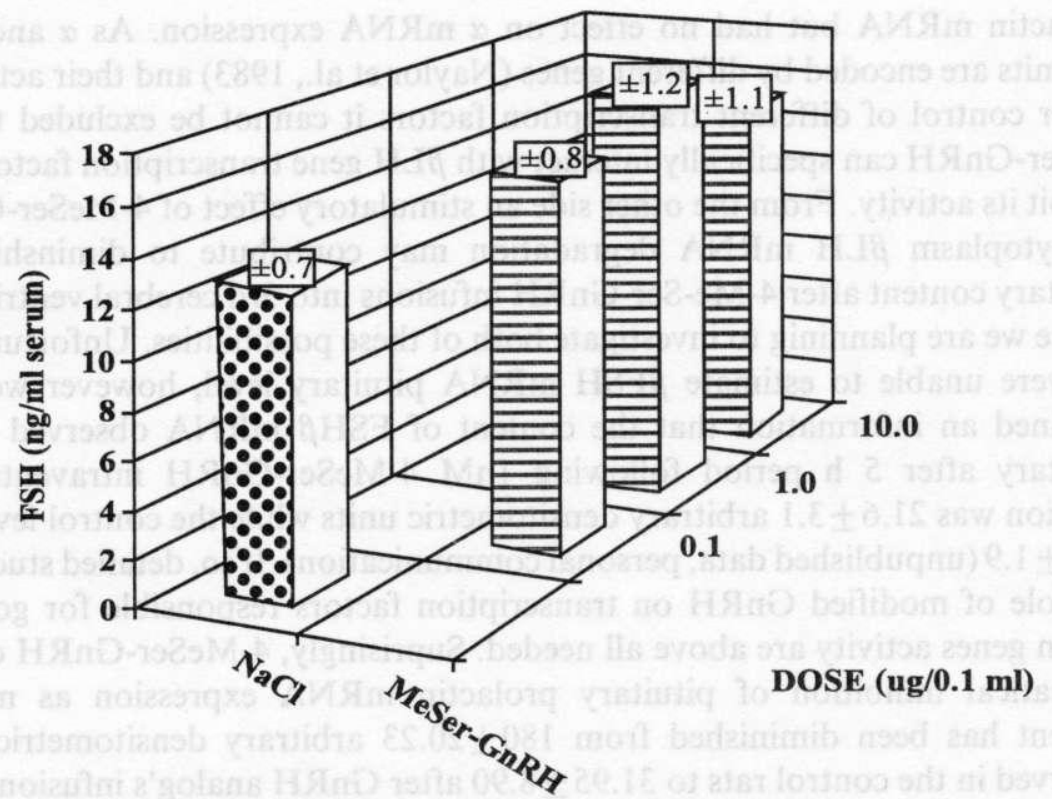

Figure 4. Serum FSH release after increasing doses of 4-MeSer-GnRH i.v. injection

FSH release while its $\mathrm{LH}$ releasing potency was minimal as it was estimated after 15 min following i.v. injection (Kochman and Gajewska, 1990). In this experiment we used next peptide's preparation vial and our results have shown the same as before tendency concerning 4-MeSer-GnRH activity: no effect on LH release and the stimulation of FSH release though such specific FSH release observed in this experiment was not so much expressed as before. It seems that modification in primary GnRH structure (MeSer in position 4) results in loosing its native properties to release both gonadotropins but an unique ability to selective FSH release is then manifested. Lack of LH stimulation release supports the idea that such modified GnRH analog does not exert its influence through pituitary GnRH receptor. If so, it is possible that 4-MeSer-GnRH can posses a partial binding property to several pituitary membrane receptors including activin receptor. But it must be stressed out that such suggestion needs further and detailed studies on conformational structure of the analog as well as systematic studies on interactions between various pituitary receptors' and 4-MeSer-GnRH in vivo and in vitro are needed to precise explanation both its ability to provoke specific FSH releasing potency as well as recognizing which pituitary receptor systems can be involved in that process. We have also investigated how 4-MeSer-GnRH can act on genes' expression in pituitaries in vivo. This peptide exerted an inhibitory action both on $\mathrm{LH} \beta$ and very strongly on 
prolactin mRNA but had no effect on $\alpha$ mRNA expression. As $\alpha$ and $\beta$ LH subunits are encoded by different genes (Naylor et al., 1983) and their activity is under control of different transcription factors it cannot be excluded that 4MeSer-GnRH can specifically interact with $\beta \mathbf{L H}$ gene transcription factors and inhibit its activity. From the other side an stimulatory effect of 4-MeSer-GnRH on cytoplasm $\beta$ LH mRNA degradation may contribute to diminshing its pituitary content after 4-Me-Ser-GnRH infusions into 3 rd cerebral ventricle. In future we are planninig to investigate both of these possibilities. Unfortunately, we were unable to estimate $\beta$ FSH mRNA pituitary level, however we have obtained an information that the content of $\mathrm{FSH} \beta$ mRNA observed in the pituitary after $5 \mathrm{~h}$ period following $1 \mathrm{nM} 4-\mathrm{MeSer}-\mathrm{GnRH}$ intraventricular infusion was $21.6 \pm 3.1$ arbitrary densitometric units while the control level was $20.8 \pm 1.9$ (unpublished data, personal communication). If so, detailed studies on the role of modified GnRH on transcription factors responsible for gonadotropin genes activity are above all needed. Suprisingly, 4-MeSer-GnRH caused dramatical inhibition of pituitary prolactin mRNA expression as mRNA content has been diminished from $180 \pm 20.23$ arbitrary densitometric units observed in the control rats to $31.95 \pm 8.90$ after GnRH analog's infusion. Such result indicate that this peptide can be involved in repression of PRL gene transcription. It was shown (Cao et al., 1987; Nelson et al., 1988) that Pit-1 factor is required for activation of PRL gene expression by binding with DNA elements within the PRL promoter region and Day and Day (1994) reported that altenatively spliced form of Pit-1 represses prolactin gene expression. It would be very interesting to determine if modified GnRH can influence on Pit-1 expression and its splicing and if this is the way through which 4-MeSer-GnRH exerts its inhibitory role on prolactin gene expression.

\section{CONCLUSIONS}

We suggest that MeSer-GnRH does not interact with GnRH receptor but partially binds to the activin receptor on the pituitary plasma membranes and cause slight selective FSH release.

\section{ACKNOWLEDGMENTS}

The authors thank the National Institute of Diabetes, Digestive and Kidney Diseases of the National Institutes of Health for generous gift of reagents for rat LH and FSH RIA. Authors want to thank very much Dr. A. Olma and professor M. Leplawy (Technical University, Lódź) for 
providing 4-MeSer-GnRH for this investigation. The valuable technical assistance of Mrs Danuta Kordowska and Miss Katarzyna Kozłowska is gratefully acknowledged.

\section{REFERENCES}

Afione S., Debeljuk L., Seilicovich A., Pisera D., Lasaga M., Diaz M.C., Duvilanski B., 1990. Substance $P$ affects the GABAergic system in the hypothalamo-pituitary axis. Peptides, 11, 1065-1068

Andrews W.V., Maurer R.A., Conn P.M., 1988. Stimulation of rat luteinizing hormone- $\beta$ messenger RNA levels by gonadotropin releasing hormone. Apparent role for protein kinase C. J. Biol. Chem. 263, 13755-13761

Attardi B., Keeping H.S., Winter S.J., Kotsuji F., Maurer R.A., Troen P., 1989. Rapid and profound suppression of messenger RNA encoding $\mathrm{FSH} \beta$ by inhibin from primate Sertoli cells. Mol. Endocrinol. 3, 280-287

Bilezikjian L.M., Corrigan A.Z., Vale W.W., 1990. Activin-A modulates growth hormone secretion from cultures of rat anterior pituitary cells. Endocrinology, 126, 2369-2376

Bilezikjian L.M., Blount A.L., Campen C.A., Gonzalea-Manchon C., Vale W., 1991. Activin-A inhibits POMCmRNA accumulation and ACTH secretion of AtT20 cells. Mol.Endocrinol. 5, 1389-1395

Billestrup N., Gonzalez-Manchon C., Potter E., Vale W., 1990. Inhibition of somatotroph growth and $\mathrm{GH}$ biosynthesis by activin in vitro. Mol. Endocrinol. 4, 356-362

Bonavera J.J., Kalra S.P., Kalra P.S., 1993. Evidence that LH suppression in response to inhibitory neuropeptides b-endorphin, interleukin $1-\beta$ and neuropeptide $\mathrm{K}$ may involve excitatory amino acids. Endocrinology, 133, 178-182

Bonavera J.J., Kalra S.P., KalraP.S., 1996. L-arginine/NO amplifies the magnitude and duration of the LH surge induced by $\mathrm{E}_{2}$. Involvement of NPY. Endocrinology, 137, 1957-1962

Brann D.W., 1995. A major excitatory transmitter in neuroendocrine regulation. Neuroendocrinology, 61, 213-225

Braden T.D., Conn P.M., 1993. GnRH and its mechanism of action. In: Leung P.C.K., Hsueh A.J.W., Friesen H.G. (eds) Molecular Basis of Reproductive Endocrinology. Springer-Verlag, New York, 12-38

Cao Z., Barron E.A., Carrillo A.J., Sharp Z.D., 1987. Prolactin upstream factor I mediates cell specific transcription. Mol. Cel. Biol. 7, 3402-3408

Carrol R.S., Corrigan A.Z., Gharib S.D., Vale W., Chin W.W., 1989. Inhibin, activin and follistatin: regulation of follicle- stimulating hormone messenger ribonucleic acid levels. Mol. Endocrinol. 3, 1969-1976

Corbani M., Counis R., Wolińska-Witort E., d'Angelo-Bernard G., Moumni M., Jutisz M., 1990. Synergistic effects of progesterone and oestradiol on rat LH subunit mRNA. J. Mol. Endocrinol. 4, 119-125

Counis R., Jutisz M., 1991. Regulation of pituitary gonadotropin gene expression. Trends Endocrinol. Metab. 2, 181-187

Counis R., Corbani M., Bérault A., Théoleyre M., Jansem de Almeida Catanho M.T., Jutisz M., 1981. Une microméthode permettant de préparer et de traduire l'acide ribonucléique messager partir de cellules adénohypophysaires en culture. C.R.Acad. Sci. Paris 293, 115-118

Day R.N, Day K.H., 1994. An alternatively spliced form of Pit-1 represse prolactin gene expression. Mol. Endocrinol., 8, 374-381 
Gharib S.D., Wierman M.E., Shupnik M.A., Chin W.W., 1990. Molecular biology of the pituitary gonadotropins. Endocr. Rev. 11, 177-199

Katayama T., Conn P.M., 1994. Activin modulates the intracellular signaling system activated by gonadotropin-releasing hormone: dual effect on calcium messenger system and protein kinase-C pathway. Endocrinology, 134, 119-125

Kitaoka M., Kojima I., Ogata E., 1989 Activin A: a modulator of multiple types of anterior pituitary cells. Biochem. Biophys. Res. Commun. 157, 48-54

Knobil E., 1980. The neuroendocrine control of the menstrual cycle. Recent Prog. Horm. Res. 36, $53-88$

Kochman K., Gajewska A., 1990. Factors affecting the FSH release from the pituitary of the female rat in vivo. Neuroendocrinology $52 / \mathrm{S} 1 / 90,94$

Kochman K., Gajewska A., 1996. Biosynthesis of gonadotropins in vivo. Acta Neurobiol. Exp. 56, 753-756

Leonhardt S, Seong J.Y., Kim K., Thorum Y., Wuttke W., Harry H., 1995. Activation of central GABA-A but not GABA-B receptor rapidly reduce $\mathrm{LH}$ release and GnRH gene expression in the preoptic/anterior hypothalamic area of ovariectomized rats. Neuroendocrinology, 61, 655-662

McMasters G.K., Carmichael G.G., 1977. Analysis of single- and double stranded nucleic acids on polyacrylamide and agarose gels by using glyoxal and acridine orange. Proc. Natl. Acad. Sci. USA. $74,4835-4838$

Naylor S.L., Chin W.W., Goodman H.M., 1983. Chromosome assignment of genes encoding the $\alpha$ and $\beta$ subunits of glycoprotein hormones in man and mouse. Somatic Cell and Mol.Genet. 9, 757.770

Nelson C., Albert V., Elsholtz H., Lu Le-W, Rosenfeld M., 1988. Activation of cell specific expression of rat growth hormone and prolactin genes by a common transcription factor. Science $239,1400-1405$

Starzec A., Moumni M., d'Angelo-Bernard G., Lerrant Y., Bouamoud N., Jutisz M., Counis R., 1989. Stimulation de l'expression des genes de LH par le GnRH:role des proteines kinases A et C. Pathol. Biol. 37, 809-813

Vale W., Hsuch A., Rivicr C., Yu J., 1990. The inhibin/activin family of hormones and growth factors. In: Sporn M.B., Roberts A.B.(eds) Handbook of Experimental Pharmacology. Springer-Verlag, Berlin. 95/II, 211-248

Xu B., Kalra P.S., Hyde J.F., Crowley W.R., Kalra S.P., 1996. An interactive physiological role of NPY and galanin in pulsatile pituitary LH secretion. Endocrinology, 137, 5297-5302

\section{STRESZCZENIE}

\section{Wplyw 4-MeSer-GnRH na uwalnianie i synteze gonadotropin in vivo}

Celem obecnego doświadczenia było potwierdzenie selektywnego uwalniania FSH przez analog natywnego GnRH (4-MeSer-GnRH), a także określenie czy ten analog działa na ekspresję genów gonadotropin i prolaktyny. W badaniach in vivo wykazano, że aktywność uwalniająca 4-MeSer-GnRH byla mniejs7a niż poprzednio w stosunku do FSH i że ten peptyd nie wpływał na uwalnianie LH. Po raz pierwszy wykazano, iż analog GnRH hamował syntezę mRNA zarówno prolaktyny jak również $\mathrm{LH} \beta$, lecz ten efekt był większy w stosunku do mRNA prolaktyny. Obecne doświadczenia wskazują, że należy podjąć dalsze szczegółowe badania nad własnościami biologicznymi 4-MeSer-GnRH. 